\title{
$\begin{array}{ll}\text { Research Square } & \begin{array}{l}\text { Preprints are preliminary reports that have not undergone peer review. } \\ \text { They should not be considered conclusive, used to inform clinical practice, } \\ \text { or referenced by the media as validated information. }\end{array}\end{array}$
}

\section{Reduction of chronic malnutrition risk and chronic malnutrition through a public health intervention in children under one year of age in Bogotá, Colombia}

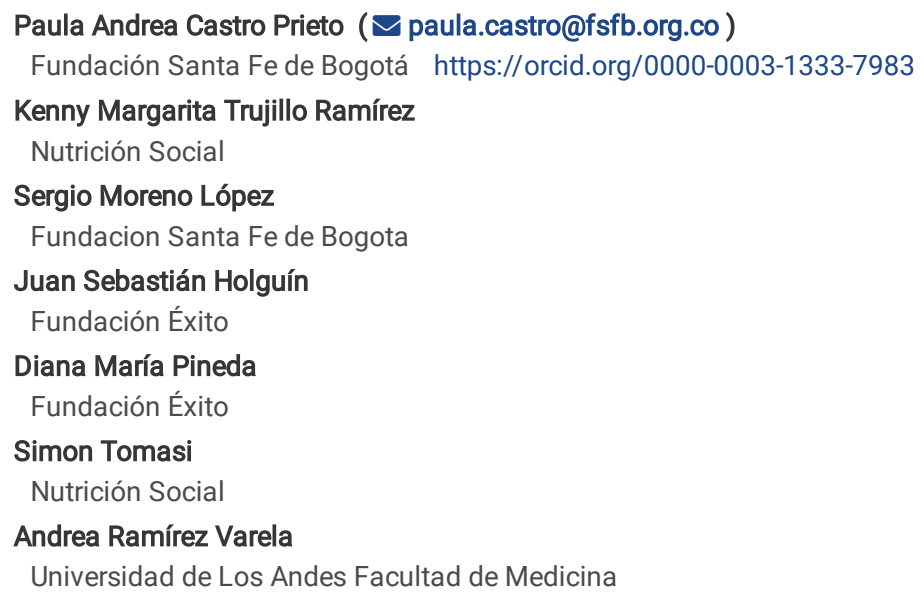

Version of Record: A version of this preprint was published at BMC Public Health on April 8th, 2021. See the published version at https://doi.org/10.1186/s12889-021-10620-3. 


\section{Abstract}

Background: As Bogotá is one of the regions with the highest prevalence of chronic malnutrition (13\%) in Colombia, exceeding the national figure of $10.8 \%$, a public-private alliance was established to address this situation within the framework of intersectoral action: the private organizations Fundación Santa Fe de Bogotá and Fundación Éxito, local government agencies of the Mayor's Office of Bogotá (Secretaría Distrital de Salud and the Secretariat de Integración Social) and agencies at the national level (Instituto Colombiano de Bienestar Familiar [Colombian Institute of Family Welfare], including its regional office in Bogotá). Therefore, the objective was to determine the effectiveness of an intersectoral public health intervention with the population under one year of age, classified as at risk of chronic malnutrition and with chronic malnutrition by anthropometry, residing in 3 prioritized territories of the Capital District.

Methods: Pre-experimental, before and after study that sought to determine the magnitude of the change in nutritional status in children under one-year-old residing in 3 prioritized territories of Bogotá through a ten months public health nutrition intervention.

Results: The intervention comprised 1126 children living in the following territories in Bogotá: Kennedy, San Cristóbal, and Engativá. A total of $43.3 \%$ children presented delay in height for age, and $56.7 \%$ presented risk of short stature. In the final measurement, data were obtained from 686 children, identifying that $17 \%$ of the children progressed from stunting to a stunting risk and that $4.5 \%$ recovered their growth trajectory, achieving an adequate height for their age.

Conclusions: That children classified as at risk or stunting at the beginning of the intervention showed an increased probability of approaching or being in the appropriate growth trajectory according to the height-for-age indicator after the intervention. In addition, the risk of stunting is a reversible condition if interventions are implemented in a timely manner and with intersectoral action for which it is imperative to link the community itself as a key sector for direct action and to organize all actors and sectors having missionary purposes with this population.

\section{Background}

Childhood chronic malnutrition corresponds to stunting, measured using the height-for-age indicator, and is classified as such when height is below 2 standard deviations (<-2 SD) with respect to the median child growth from the World Health Organization. Worldwide, at the end of 2018, stunting affected 149 million children under five years of age and 4.8 million children in Latin America ${ }^{(1)}$.

Delay in height is the consequence of poor nutrition, repeated infections, and inadequate psychosocial stimulation during the first 1000 days of life (2). Height is a determinant of child development because it is not only a matter of centimeters gain but also of the development of all functions and organs in the body, including the brain, which has great repercussions on learning capacity ${ }^{(3)}$.

Being stunted before two years of life and not overcoming it becomes a predictive factor of low school performance and the appropriation of skills at later ages, outcomes that negatively affect the economic development of both individuals and collectives in communities and countries ${ }^{(2)}$. In economic terms, stunting is related to productivity, with implications on the economic development of countries. It is estimated that children with stunting may lose two or three years of school and have $23 \%$ less income in their adult life, resulting in a $3 \%$ reduction in the gross domestic product (GDP) of countries at the national level (4).

Stunting, in addition to being the "best general indicator" of the level of well-being of children, is also a "reflection" of the social inequalities that affect a territory. It has been described that stunting "is a symptom of deficiencies of the past and an indicator of poverty in the future" (2).

According to UNICEF, in 2019, one in three children under five years of age in the world is not growing well because they suffer from stunting, acute malnutrition or overweight and, in some cases, manifest up to two of these forms of malnutrition. In addition, there are children who suffer from hidden hunger, that is, micronutrient deficiencies that seriously affect both their survival and growth and development in all stages of life ${ }^{(1)}$.

Colombia is no exception, and according to the 2015 National Survey of the Nutritional Situation (Encuesta Nacional de la Situación Nutricional - ENSIN), the prevalence of stunting in children under five years of age was $10.8 \%$, with a higher prevalence in boys compared to girls, $12.1 \%$ vs. $9.5 \%$; In terms of region, Bogotá, presented the highest prevalence rate (13\%), a figure that exceeded national records ${ }^{(5)}$.

Given that Bogotá was the most affected region in the country and the negative consequences of stunting on children's growth and development potential, an intervention to generate knowledge for action was needed. A public-private alliance was created between the local government (Mayor of Bogotá and its secretariats of health and social integration), a representative of the national government (Colombian Institute of Family Welfare, Instituto Colombiano de Bienestar Familiar - ICBF) and non-governmental organizations recognized in Colombia for their commitment to nutrition during childhood: Fundación Éxito and Fundación Santa Fe de Bogotá.

With the collaboration of these allies, it was decided to develop a pilot study involving a public health intervention with residents of Bogotá under one year of age with nutritional classification by anthropometry compatible with stunting risk or stunting. The general objective was to determine the effectiveness of an intersectoral public health intervention with the population under one year of age, classified as at risk of stunting and with stunting by anthropometry, residing in three prioritized territories of the Capital District.

The study was conducted in four phases: 1) recognition of the territorial capacities of the different sectors for early childhood, 2) construction of a stunting baseline and of its determinants for each prioritized territory, 3) implementation of the intervention, and 4) post-intervention measurement.

The results of this study, were used for the construction of a guide for the prevention and management of chronic malnutrition and its risk as an event of interest in public health; the guide may serve as an instrument of public policy with scaling up potential in other territories.

Page 2/13 


\section{Methods}

\section{Study design}

This was a pre-experimental study, with before and after intervention analyses, to determine the magnitude of the change in nutritional status determined by anthropometry of children under one year of age residing in three prioritized territories of Bogotá, exposed to an intersectoral public health intervention for 10 months.

\section{Sample}

1126 children younger than 10 months of age with anthropometric nutritional classification compatible with a risk of short stature (height/age indicator cutoff point $\geq-2$ to $<-1$ ) and/or chronic malnutrition (cut-off point $<-2$ ) were recruited. The sample size considered resources available to develop the intervention in the territory, in the time foreseen as the minimum feasible intervention to achieve changes in the population to be intervened.

\section{About The Selection of The Sample}

Available economic resources allowed recruiting and following up a maximum number of subjects in three out of 20 territories in which Bogotá is divided. To select these territories, the 2017 and 2018 databases from epidemiological surveillance systems were reviewed. Selection was conducted according to mother's residence, the highest number of children under two years of age with chronic risk of malnutrition or malnutrition and, history of low birth weight. Five of the 20 territories accounted for $47 \%$ of the cases and, Engativá, Kennedy and San Cristóbal, which are in different latitudes of the city, were identified as the three territories with the greatest number of cases [see additional file 1].

\section{Regarding The Recruitment Of Subjects}

1752 children were screened, of whom 1126 voluntarily agreed to participate in the study and met the following inclusion criteria:

- Children with the height-for-age indicator (H/A) less than - 1 SD;

- Children aged ten months or younger at study entry;

- Product of a full-term pregnancy (birth from 37 weeks or more); and

- Resident of any of the three prioritized territories.

The defined exclusion criteria were as follows:

- Product of multiple pregnancies;

- Place of residence different from Bogotá;

- Any special health condition (disability);

- Congenital pathology;

- Confirmed diagnoses of diseases requiring pharmacological treatment with hormone therapy and/or special diets preventing compliance with the recommendations of complete, balanced, sufficient, and adequate nutrition for healthy children; and

- Families not consenting study participation.

\section{Intervention Model:}

The intervention was designed according to evidence-based recommended actions, adopted and regulated by Colombia ${ }^{(6)}$ and, the Evidence-Based Clinical Practice Guide ${ }^{(7)}$ to achieve adequate health and nutrition in early childhood. This intervention model (Fig. 1) focused on actions throughout the first 1000 days of life (from conception through the first two years of life), and included the following axes:

- Health care: provided specific information to families about the health care each child should receive according to their age and current condition. Individual needs were identified through baseline interviews.

- Social care: included actions to guide families to early education care and the social benefits available in each territory. As part of the development of this axis, a pedagogical food supplementation strategy was implemented through the delivery of redeemable vouchers in supermarkets that had to be exchanged in order to get a pre-established list of healthy foods (determined by nutritionists in the team). The foods obtained from the voucher should contribute $33 \%$ of the daily caloric requirements and $100 \%$ of the protein requirements, which would be additional to what the children received at home or in other social programmes. Compared to other sources of food supplementation, the voucher was used to provide nutritious foods that would strengthen the nutritional recovery of children, mainly associated with the contribution of protein of high biological value and energy from healthy sources [see additional file 4].

- Caregiver education: considered as the linkage of all axes and actions. Therefore, face-to-face workshops were held for fathers, mothers and other caregivers regarding food and nutrition, parenting, and development guidelines, all specific to age groups and using innovative methodologies that would allow the greatest appropriation of knowledge to be applied for the care of children.

- Community empowerment. its purpose was to achieve the sustainability of the actions that were developed in the other components beyond the time of the study and the adherence to them to benefit more children in the territories. Its development included characterization and participation in the intersectoral workspaces of each territory undergoing the intervention and Bogotá as a city from the central government, in addition to the deployment of a communication strategy with various tools. 
The distribution of study beneficiaries according to participation in the activities defined for the intervention can be consulted in the Fig. 2 .

\section{Data Collection}

Collection of baseline information was conducted between May and July 2018. Post-intervention measurement was developed between May and August 2019.

The dependent variable was the magnitude of the change in nutritional status determined by anthropometry in the height-for-age indicator ( $\mathrm{H} / \mathrm{A}$ ). Appropriate height for age was defined as $\geq-1$ standard deviation (SD), risk of short stature was defined as $\geq-2$ and $<-1$ SD, and delay in height was defined as $<-2$ SD (8).

The independent variables were determinants of the nutritional status of individuals:

- Feeding: exclusive and continued breastfeeding practices and adequate complementary diet;

- Nutrition: weight and height;

- Health: history of pregnancy, tracking growth'p, vaccination, supplementation and home enrichment with micronutrients, educational messages;

- Social: redemption and use of food vouchers destined to strengthen the feeding of the breastfeeding mother and that children strengthen their complementary feeding; and participation/connection with social programmes; and

- Socioeconomic and demographic context. locality of residence, household income, female head of household, mother's schooling, mother's age and child's age.

\section{Tools}

For the analysis, the frequency of food consumption for children under two years validated by the ENSIN was used ${ }^{(5)}$.

\section{Statistical analysis:}

To analyse the effects of the intervention on the nutritional status measured by anthropometry via $\mathrm{H} / \mathrm{A}$ and the factors associated with $\mathrm{H} / \mathrm{A}$ changes (comparing baseline and final post-intervention measurements), statistical analysis was performed using a multivariate logistic regression model.

For the purposes of the model, the dependent variable was constructed by comparing the nutritional status via the first and second $\mathrm{H} / \mathrm{A}$ measurements (baseline and post-intervention measurements). A positive effect of the intervention was defined as presenting height-for-age with a positive trend suggestive of an approach to the appropriate growth trajectory or presenting a H/A compatible with being in the normal growth trajectory. The above required fulfilment of the following 2 conditions: 1) a comparison between the baseline and the final measurements and 2) having participated in all the components of the intervention (education, social assistance from the redemption of pedagogical food vouchers and health monitoring).

The independent variables of the model were defined as follows (throughout the sample):

- Territory: Kennedy was used as an adjustment variable in the model as a reference category;

- Educational level of the mother: although the primary reference category presented a lower number of observations than the other categories;

- Socioeconomic variables: these were not included in the model because more than $95 \%$ of the sample had access to basic public services; and

- Adherence to workshops: this variable was not included in the model because consolidated attendance at workshops by beneficiaries exceeded $95 \%$ [see additional file 2].

Regarding the diagnosis and adjustment of the model, there were no collinearity problems. In turn, the goodness of fit tests did not reject the null hypothesis of the model fit and did not present leverage problems. For the residuals, five atypical points were detected. After a sensitivity analysis with a power of $80 \%$, these points were removed from the final model because the magnitude of the coefficients did not exceed $5 \%$, and the goodness of fit statistics (AIC and BIC) were excluded for the final model. Finally, ROC curve analysis revealed an area under the curve of 72.11 and a percentage of correct classification of $75 \%$.

\section{Results}

\section{Baseline.}

A total of 1126 children were recruited in the three prioritized localities. $42.81 \%$ of the sample lived in Engativá, while $30.02 \%$ and $27.18 \%$ lived in Kennedy and San Cristóbal, respectively (Table 1).

Regarding gender, $52.84 \%$ of the children were male, and $47.16 \%$ were female. In terms of age group, $55.60 \%$ of children were younger than six months, and $44.40 \%$ were older than six months. The main caregiver was mothers $(87.74 \%)$. A total of $40.59 \%$ of these mothers had completed their high school education. 
Table 1

Distribution of participants by location,

baseline.

\begin{tabular}{|lll|}
\hline Locality & Frequency & Percentage \\
\hline Engativá & 482 & 42.81 \\
\hline Kennedy & 338 & 30.02 \\
\hline San Cristóbal & 306 & 27.18 \\
\hline Total & 1126 & 100 \\
\hline
\end{tabular}

For anthropometric nutritional status (Table 2), $43.25 \%$ of the children were classified with height delay for age, and $56.75 \%$ were at risk of short stature. Of the variables obtained to assess feeding practices, for exclusive breastfeeding, less than 4 out of 10 children (37.80\%) younger than 6 months were exclusively breastfed; San Cristóbal (40.65\%) was the territory with the highest prevalence of the practice, followed by Engativá (38.15\%), and Kennedy (35.32\%).

Table 2

Distribution of participants according to nutritiona status by anthropometry, height/age indicator, baseline

\begin{tabular}{|lll|}
\hline Height/age & Frequency & Percentage \\
\hline Delay in height & 487 & 43.25 \\
\hline Risk of short stature & 639 & 56.75 \\
\hline Total & 1126 & 100 \\
\hline
\end{tabular}

For adequate complementary diet, eight out of ten participants (81.0\%) between six and eight months had adequate introduction of food consistencies. The consumption of food sources of protein such as eggs was reported for $31.20 \%$ of the children, while meat, fish, chicken and other food sources of animal protein were consumed by $49.20 \%$ of the children.

\section{Post-intervention final measurement.}

For the final measurement performed at the end of the ten-month intervention, the legal caretakers of the participants were contacted. Data and postintervention measurements were collected from 686 children (the reduction in the sample was due to transfers from the participants' place of residence). In this phase, before and after comparisons were performed and for this analysis, children without final measurements were not included.

The reason why we did not conduct data imputation is that height is a biological variable that changes during childhood, even with stunting. Additionally, from the statistical point of view, a statistical power of $80 \%$ was achieved with 686 final participants. Therefore, the comparisons described below correspond to 686 children that have both baseline and final post-intervention measurements.

The geographic distribution of participants measured in the post-intervention period can be found on Table 3 . Regarding gender, $47.23 \%$ were female, and $52.77 \%$ were male. The age distribution was as follows: $64.58 \%$ were children between 12 and 18 months, $22.16 \%$ were children older than 18 months, and $13.27 \%$ were children between nine and 11 months. Similarly, it was found that mothers were the main caregivers (71.87\%). Of this group, almost a quarter (22.11\%) reported having completed technical or technological studies.

Table 3

Distribution of the participants by locality of residence, post-intervention final measurement.

\begin{tabular}{|lll|}
\hline Locality & Frequency & Percentage \\
\hline Engativá & 285 & 41.55 \\
\hline Kennedy & 189 & 27.55 \\
\hline San Cristóbal & 170 & 24.78 \\
\hline Other locations & 42 & 6.12 \\
\hline Total & 686 & 100 \\
\hline
\end{tabular}

Regarding the health variables in the post-intervention measurement, $19.10 \%$ of caregivers reported not having a growth and development card (in Colombia, all children under five years have a card that includes the growth and development chart and nutrition records that caregivers have to bring to every consultation) and having this card was determined as evidence of adherence to this health care. At baseline, this figure was $35.90 \%$; that is, this variable improved by 16.90 percentage points. Concerning the recommended care for the early detection of growth and development disorders in children, only $35.3 \%$ met the number of consultations required for their age. 
In terms of nutritional status by anthropometry (Table 4) and [see additional file 3], $17.06 \%$ of the children transitioned from stunting to risk of short stature, while $4.52 \%$ (31 children) advanced to an appropriate H/A. For the risk of short stature, $21.57 \%$ (146 children) progressed towards adequate $\mathrm{H} / \mathrm{A}, 29.59 \%$ maintained a risk of short stature, and $6.56 \%$ reported stunting. For the weight-for-height indicator, $2.10 \%$ of children who reported a delay in height also presented a risk or excess weight, compared to $17.90 \%$ who presented this same condition at baseline.

Table 4

Changes in the height-for-age indicator.

\begin{tabular}{|llllll|}
\hline $\begin{array}{l}\text { Anthropometric baseline } \\
\text { classification }\end{array}$ & $\begin{array}{l}\text { Post-chronic } \\
\text { malnutrition (stunting) }\end{array}$ & $\begin{array}{l}\text { Post-chronic } \\
\text { malnutrition (stunting) } \\
\text { (\%) }\end{array}$ & $\begin{array}{l}\text { Post-risk of } \\
\text { short stature }\end{array}$ & $\begin{array}{l}\text { Post-risk of short } \\
\text { stature (\%) }\end{array}$ & $\begin{array}{l}\text { Post- } \\
\text { adequate } \\
\text { height }\end{array}$ \\
\hline Chronic malnutrition & 142 & 20.70 & 117 & 17.06 & $\begin{array}{l}\text { Post- adequate } \\
\text { height (\%) }\end{array}$ \\
\hline Risk of short stature & 45 & 6.56 & 203 & 29.59 & 14.52 \\
\hline Total & 187 & 27.26 & 320 & 46.65 & 21.57 \\
\hline
\end{tabular}

For the variables related to feeding practices, continued breastfeeding was reported by $73.70 \%$ of the participants. In turn, at baseline, $29.20 \%$ reported consuming eggs, which are a source of protein of high biological value and are easy to access, and in the final post-intervention measurement, $83.32 \%$ reported consuming eggs. At baseline, $45.20 \%$ reported consuming other food sources of animal protein, while in the final measurement, this value increased to $90.21 \%$. The redemption of the voucher achieved $93.51 \%$ adherence throughout the intervention.

\section{Multivariate Logistic Regression Model}

\section{Model results}

According to Table 5 and Fig. 3, the statistically significant results suggest that children classified as at risk of stunting or with stunting at the beginning of the intervention showed an increased probability of approaching or being in the appropriate growth trajectory according to the height-for-age indicator after the intervention. However, this probability decreased if children were at risk of stunting or had stunting at older ages, as follows: for each additional month of age that elapsed for the identification of risk or stunting, the probability of approaching or entering an adequate growth trajectory with an intersectoral nutritional intervention decreased by $20.1 \%$ (OR: $0.7995 \% \mathrm{Cl}$ : $0.70-0.90 \mathrm{p}<0.001$ ). 
Table 5

Multivariate logistic regression model presenting the probability of approaching or being in the appropriate growth

\begin{tabular}{|c|c|c|c|c|c|}
\hline \multirow{2}{*}{$\begin{array}{l}\text { Variable } \\
\text { Height-for-age z-score }\end{array}$} & \multirow{2}{*}{$\begin{array}{l}\text { Coefficient (OR) } \\
0.51\end{array}$} & \multirow{2}{*}{$\begin{array}{l}\text { Standard error } \\
0.09\end{array}$} & \multicolumn{2}{|c|}{ Confidence interval } & \multirow{2}{*}{$\begin{array}{l}\text { p-value } \\
0.000\end{array}$} \\
\hline & & & 0.36 & 0.73 & \\
\hline Age in months & 0.79 & 0.05 & 0.70 & 0.90 & 0.001 \\
\hline \multicolumn{6}{|l|}{ Reference category (first child) } \\
\hline Second child or older & 0.90 & 0.19 & 0.59 & 1.36 & 0.626 \\
\hline \multicolumn{6}{|l|}{ Reference category (locality 1) } \\
\hline Locality 2 & 0.76 & 0.19 & 0.46 & 1.27 & 0.309 \\
\hline Locality 3 & 0.61 & 0.17 & 0.35 & 1.07 & 0.088 \\
\hline \multicolumn{6}{|l|}{ Reference category (male) } \\
\hline Female & 1.03 & 0.21 & 0.68 & 1.56 & 0.869 \\
\hline \multicolumn{6}{|l|}{ Reference category (caregiver age $<40$ years) } \\
\hline Older than or equal to 40 years & 1.87 & 0.74 & 0.85 & 4.10 & 0.115 \\
\hline \multicolumn{6}{|c|}{ Reference category (education level: elementary) } \\
\hline High school & 1.11 & 0.46 & 0.49 & 2.51 & 0.787 \\
\hline Technical or technological or professional & 1.27 & 0.57 & 0.52 & 3.07 & 0.594 \\
\hline Postgraduate & 3.02 & 2.04 & 0.80 & 11.36 & 0.102 \\
\hline \multicolumn{6}{|c|}{ Reference category (not exclusive breastfeeding) } \\
\hline Exclusive breastfeeding & 0.95 & 0.41 & 0.40 & 2.21 & 0.907 \\
\hline \multicolumn{6}{|c|}{ Reference category (non-continued breastfeeding) } \\
\hline Continued breastfeeding & 1.03 & 0.45 & 0.43 & 2.43 & 0.941 \\
\hline \multicolumn{6}{|l|}{ Reference category (canned milk consumption) } \\
\hline No consumption of canned milk & 0.54 & 0.13 & 0.32 & 0.89 & 0.017 \\
\hline \multicolumn{6}{|l|}{ Reference category (no fruit consumption) } \\
\hline Fruits & 0.77 & 0.42 & 0.26 & 2.29 & 0.648 \\
\hline \multicolumn{6}{|c|}{ Reference category (no consumption of vegetables) } \\
\hline Vegetables & 1.60 & 0.51 & 0.85 & 3.00 & 0.138 \\
\hline \multicolumn{6}{|c|}{ Reference category (no consumption of protein sources) } \\
\hline Protein sources & 1.46 & 0.46 & 0.78 & 2.73 & 0.232 \\
\hline \multicolumn{6}{|c|}{ Reference category (no consumption of legumes) } \\
\hline Legumes & 1.90 & 0.42 & 1.22 & 2.95 & 0.004 \\
\hline \multicolumn{6}{|c|}{ Reference category (no minimum frequency of consumption) } \\
\hline Minimum frequency of consumption & 1.72 & 0.61 & 0.85 & 3.45 & 0.126 \\
\hline \multicolumn{6}{|l|}{ Reference category (no monitoring 1) } \\
\hline Monitoring 1 & 1.74 & 1.23 & 0.43 & 6.94 & 0.427 \\
\hline \multicolumn{6}{|l|}{ Reference category (no monitoring 2) } \\
\hline Monitoring 2 & 0.43 & 0.50 & 0.46 & 4.14 & 0.472 \\
\hline \multicolumn{6}{|l|}{ Reference category (less than 9 vouchers) } \\
\hline 9 or more vouchers & 0.73 & 0.18 & 0.44 & 1.20 & 0.223 \\
\hline \multicolumn{6}{|l|}{ Reference category ( $\leq 1.0$ CLMW) } \\
\hline$>1.0$ CLMW & 1.53 & 0.32 & 1.01 & 2.31 & 0.043 \\
\hline \multicolumn{6}{|c|}{ Reference category (non-mother head of household) } \\
\hline Mother head of household & 1.53 & 0.32 & 1.00 & 2.33 & 0.045 \\
\hline
\end{tabular}




\begin{tabular}{|llllll|}
\hline Variable & Coefficient (OR) & Standard error & Confidence interval & $\mathrm{p}$-value \\
\hline Constant & 3.44 & 5.59 & 0.14 & 82.8 & 0.445 \\
\hline number of observations & 571 & & & & \\
\hline
\end{tabular}

At the beginning of the intervention, children who were six months or younger and at risk of stunting or with stunting, had more than a $70.0 \%$ probability of approaching or entering their proper growth trajectory after intervention. In contrast, children older than six months had less than a $70.0 \%$ probability.

In addition, when these children had mothers that self-reported as heads of household, there was more than a $70 \%$ probability of approaching or entering their proper growth trajectory once receiving the intervention; in comparison, children older than six months had less than a $70 \%$ probability.

In contrast, the probability of approaching or being in the appropriate growth trajectory for the height-for-age indicator, post-intervention, decreased if children were at risk of stunting or with stunting at older ages and mothers were not recognized as heads of household.

Concerning the food component, the probability of approaching or being in the proper growth trajectory after the intervention decreased by $45.9 \%$ (OR: 0.57 $95 \% \mathrm{Cl}: 0.32-0.89 \mathrm{p}<0.017)$ if the children were fed formula milk compared to those who were not fed formula milk during the course of the intervention. Likewise, the probability of approaching or being in the proper growth trajectory after the intervention increased by $90.5 \%$ (OR: 1.90 95\% Cl: $1.22-2.95 \%$ : $\mathrm{p}<$ 0.004) for those who included vegetables in the diet compared to those who did not consume vegetables during the course of the intervention.

Regarding sociodemographic data, the probability of approaching or being in the appropriate growth trajectory after the intervention increased by $53 \%$ (OR: $1.5395 \% \mathrm{Cl}: 1.01-2.31 \%$ : $\mathrm{p}$ 0.043) for the children of households with an income greater than 1.0 current legal minimum wage (CLMW) compared to children of households with an income lower than $1.0 \mathrm{CLMW}$ during the course of the intervention. This probability also increased by $53.7 \%$ (OR: $1.5395 \% \mathrm{Cl} 1.00-$ 2.33\%: $p<0.045$ ) for children in families with female heads of households compared to children in families with male heads of households.

\section{Discussion}

This study shows how a model of intersectoral intervention, to which a group of children under one year of age was exposed for ten months, was able to change the nutritional status, as measured by anthropometry, i.e., $\mathrm{H} / \mathrm{A}$ indicator, in $43.14 \%$ of the participants undergoing the intervention. Four children out of ten moved positively in their growth trajectory; these results were based on final post-intervention measurements.

After the intervention, the group of children who showed a positive change in height <-2 standard deviations (4.52\%), that is, classified as stunting, moved even more positively in their growth trajectory and showed total recovery of their nutritional condition, becoming appropriate for their age. These findings, when contrasted with the scientific evidence on health and nutrition interventions focused on reducing the delay in height in children under five years, are relevant because it has been described that those interventions of greater efficacy to reduce the prevalence of delay in height in children under five years are those that at least obtained a $3.0 \%$ change in the prevalence of height delay in the intervened population, with an exposure greater than or equal to 12 months ${ }^{(9)}$.

Faced with the relationship between anthropometric indicators of $\mathrm{H} / \mathrm{A}$ and $\mathrm{W} / \mathrm{H}$, after implementing the intervention model, the prevalence of risk and/or excess weight-for-height decreased from 17.90-2.10\%; that is, only two out of ten children involved in the intervention maintained their double burden of malnutrition, a finding that shows that the actions proposed in the intervention were effective in this group because the prevalence of this double condition was reduced by slightly more than 15 percentage points and scientific evidence has catalogued as effective interventions those that achieve at least $3.0 \%$ (baseline: $17.90 \%$; post-intervention: $2.10 \%)^{(9)}$.

The result of double burden makes us reflect, as other studies have previously stated, on the importance of monitoring and intervening in height gain in early childhood as well as in issues related to adequate weight gain for height; from the perspective of public health, comprehensive policies should be established to mitigate malnutrition problems, both due to excess weight and delayed height ${ }^{(10,11)}$.

The increase in malnutrition due to excess in childhood concomitant with the delay in height is a predictor of the future presence of chronic diseases such as obesity, diabetes, dyslipidaemia and hypertension, among others ${ }^{(12)}$. Important outcomes are predictors of the quality of life of the adults who will be the fathers and mothers of the children to be born and on whom an own health and nutrition map will be established, partly inherited by the deficiencies of their parents. There is evidence that has shown how the nutritional recovery of an individual that occurs during the first two years favourably affects variables such as birth weight, schooling, human capital, and the presence or absence of future diseases ${ }^{(13)}$.

In respect to the magnitude of the change, it was found that children six months or younger who were at risk of stunting or with stunting, had a greater than $70.0 \%$ probability of approaching or entering their proper growth trajectory after intervention compared to children older than six months, who had less than a $70.0 \%$ probability. This result confirms, as several studies have described, the importance of implementing specific interventions on length delay during the most effective window of opportunity, that is, from gestation through the first two years of life $(14,12,1)$.

It was found that the probability of approaching or entering an adequate growth trajectory after intervention increased when the child was in a household where the head of household was a woman. A possible explanation for this result is argued by a study that states that empowered mothers (via head of household, for example) have fewer time restrictions to dedicate to their children, in addition to having better mental health and more control over children and household resources, greater self-esteem and better information regarding and access to health services. This implies that empowered mothers take better care of themselves and their children, which is expected to have benefits on the nutritional status of the latter ${ }^{(15)}$. 
Similarly, it has been shown that interventions that include timely education for caregivers for the age and current condition of the children, systematic monitoring, effective connection with health care and other sectors related to early childhood care, including basic sanitation and drinking water, developed in low- and middle-income countries are more effective for better outcomes related to child nutrition (9).

For example, at the end of the intervention, $80.9 \%$ beneficiary families had their comprehensive assessment of growth and development cards for their children and were able to explain their importance; their use demonstrates caregiver empowerment through exercising their rights and duties as citizens, benefiting them as a community. Necessary conditions for caregivers to effectively access health care relevant to the age of their children are key factors for the prevention and/or management of delayed height in the window of opportunity of early childhood ${ }^{(1)}$.

The educational strategy used for the intervention axis related to caregiver education was constructed using counselling as a methodology, whose principle is to work from the needs expressed by those who will be subjects of education using the skills allowing improving the process of communication between the facilitators and the participants so that they acquire the necessary skills for informed decision-making ${ }^{(16)}$.

In this study, at the end of the intervention, seven out of ten children continued breastfeeding (73.7\%) as part of their eating pattern; in comparison with the breastfeeding practice at baseline, improvement in practice was evident. Evidence has shown that using counselling contributes positively to practices related to the duration of exclusive and continued breastfeeding ${ }^{(17)}$ with adequate complementary feeding until two years and older.

Similarly, an improvement in the general practice of breastfeeding has been related as a function of maternal educational level and to mothers being immersed in protective environments and surrounded by community supporters ${ }^{(18)}$. These elements were also observed; most of the mothers had completed their high school education and a significant proportion, by the end of the intervention, had completed higher technical studies, a finding that suggests the importance of consolidating intersectoral strategies to favour the formal education of mothers and caregivers.

The probability of approaching or being in the appropriate growth trajectory, after the intervention, was reduced by $45.9 \%$ if the children were fed with formula milk compared to those who did not receive it. This result is consistent with other studies. A study conducted in public hospitals in Hong Kong found for a sample of 642 preterm children with low weight, those fed during their hospitalization with breast milk had a better z-score for height-for-age upon discharge than children fed formula milk because children fed formula have a higher risk of gastrointestinal infections that affect weight and height ${ }^{(19)}$.

These results reaffirm breast milk providing nutrients children need for healthy growth and development during their first two years and beyond; therefore, it is necessary that social programs have as a priority the promotion and protection of this practice, as established by the WHO: exclusive breastfeeding during the first six months of life and adequate complementary feeding until two years or more ${ }^{(20)}$.

According to the age of the children, $29.2 \%$ consumed eggs at baseline (older than six months), and $83.32 \%$ consumed eggs at the post-intervention measurement. That is, eight out of ten children were eating eggs as one of their main sources of protein. After the intervention, nine out of ten children (90.21\%) had food sources of animal protein as part of their eating pattern. This result could be related to food voucher delivery, part of the social focus of the intervention model.

These vouchers were redeemed monthly by each beneficiary family in the study in a local supermarket. The redemption had a list of foods that included healthy food. This list was defined taking into account the recommendations for feeding for early childhood defined by the governing body of the sector for Colombia, ICBF (21). Additionally, the proposed form of redemption favoured families having autonomy in decision-making for the purchase and preparation of food. This was mediated by the collaboration between the axes of education for caregivers and social care.

According to the evidence, the way to effectively intervene in height delays in early childhood requires comprehensive intersectoral work that encompasses cross-cutting actions that can account for most of the determinants of this condition, as the intervention of this study developed ${ }^{(12,1)}$.

In relation to the sociodemographic results:

1. Family income plays a fundamental role in the recovery of stunting. A World Bank study ${ }^{(22)}$ argues that the link between income and nutritional status occurs mainly because households with higher income levels can invest more in consumption and variety of foods, in addition to having better quality of services and more resources to invest in the care of their children. This relationship has been validated by different studies using different measures to determine income as monthly wages $(23,22)$ or assets in the home ${ }^{(24)}$, among others.

2. The obtained results of mother's education level were not consistent with scientific evidence. Different authors have referred to how the children of more educated mothers present better results for the nutritional indicator height-for-age ${ }^{(13,12,2)}$. Education empowers women to make decisions they could not make in the absence of it, such as having fewer children or using health services in a better way, which leads to greater development in their children, both physical and emotional ${ }^{(25)}$. In the present study, this relationship was not evidenced.

The intervention model implemented in the study is in line with several of the recommendations suggested by authors such as Butta, who refers to following effective actions in public health that make it possible to reduce height delays when implemented during early childhood: (i) folic acid supplementation in the preconception period; (ii) dietary supplementation to obtain a positive energy and protein balance in pregnant women; (iii) calcium supplementation for mothers; (iv) multiple micronutrient supplementation during pregnancy; (v) promotion of breastfeeding; (vi) adequate complementary feeding; (vii) administration of vitamin A; (viii) preventive zinc supplementation in children from six to 59 months; (ix) treatment of moderate acute malnutrition; and (x) treatment of severe acute malnutrition ${ }^{(26)}$.

\section{Limitations}

Page $9 / 13$ 
The sampling for this study was consecutive, and families were recruited mainly by mass communication strategies and the "snowball" technique. This sample determination did not allow us to extrapolate the results to the entire population in Bogotá. The intervention model developed and the results of the study directly pertain to the specific composition of the sample, mainly in terms of socioeconomic indicators; therefore, the magnitude of the change obtained on the height/age indicator of the beneficiaries of the study is specific to this group of children under the conditions that were treated

\section{Conclusion}

The risk of stunting and/or stunting in early childhood is a reversible condition if interventions are implemented in a timely manner and with intersectoral action, for which it is imperative to link the community itself as a key sector for direct action and to organize all actors and sectors having missionary purposes with this population; this should be done to coordinate their multiple actions on the common focus of preventing and/or treating height problems related to malnutrition. Colombia, like other countries in the region, should continue their efforts to improve the visibility of this problem and make it a priority for the development of the country.

\section{Declarations}

\section{Ethics approval and consent to participate}

The study complies with the definition in the Declaration of Helsinki regarding the development of research that involves human beings, and all legal representatives of the research subjects signed the informed consent forms acknowledging they understood what the participation of their children in the study meant. The databases created for the study were anonymized for statistical analysis, results and conclusions reporting. The study was authorized by the ethics committee of Fundación Santa Fe de Bogotá, record number CCEI-9555-2018.

\section{Consent for publication}

Not applicable.

\section{Availability of data and material}

The datasets used and/or analyzed during the current study are available from the corresponding author on reasonable request.

\section{Competing interests}

The authors declare they have no competing interests

\section{Funding}

The study was funded by Fundación Éxito and Fundación Santa Fe de Bogotá. Fundación Éxito provided the resources for the development of the research process in the different phases: characterization, baseline, intervention and final measurement. For its part, Fundación Santa Fe de Bogotá linked specialized human talent to lead the project.

\section{Authors' contributions}

Through this, we declare that the seven authors are responsible and guarantors that all the aspects that make up the manuscript have been reviewed and discussed with the maximum precision and integrity. In order of participation PCP: was the one who led the design and nterpretation of data, construction, and final revision of the article. KMT, SML, JHP: supported with the conception, construction, and final revision of the manuscript. AR: was the epidemiology consultant of the project. Similarly, DPR, ST: supported information and final document revision. All authors have read and approved the manuscript.

\section{Acknowledgements}

We thank the community of the Kennedy, San Cristobal and Engativá territories, local associations, and public entities for allowing the development of this intervention.

\section{References}

1. World Health Organization. Metas mundiales de nutrición 2025: Documento normativo sobre retraso del crecimiento; 2017. Available from: https://apps.who.int/iris/bitstream/handle/10665/255735/WHO_NMH_NHD_14.3_spa.pdf?ua=1. [cited 2020 Feb 1].

2. World Health Organization. 10 facts on nutrition; 2017. Available from: https://www.who.int/features/factfiles/nutrition/en/. [cited 2020 Feb 1].

3. La desnutrición infantil. Causas, consecuencias y estrategias para su prevención y tratamiento; 2011. Available from: https://www.unicef.es/sites/unicef.es/files/Dossierdesnutricion.pdf. [cited 2020 Feb 1].

4. El Estado Mundial de la Infancia 2019: Niños, alimentos y nutrición: crecer bien en un mundo en transformación; 2019. Available from: https://www.unicef.org/lac/informes/el-estado-mundial-de-la-infancia-2019-ni\%C3\%B1os-alimentos-y-nutrici\%C3\%B3n. [cited 2020 Feb 1].

5. Colombia, Ministerio de Salud y Protección Social, Instituto Colombiano de Bienestar Familiar, Universidad Nacional de Colombia, Instituto Nacional de Salud. Encuesta Nacional de la Situación Nutricional (ENSIN). Colombia; 2019. 
6. Ministerio de Salud y Protección Social. Rutas de Atención Integral en Salud; 2016. Available from: https://www.minsalud.gov.co/Paginas/rutasintegrales-de-atencion-en-salud.aspx. [cited 2020 Feb 1].

7. Ministerio de Salud y Protección Social. Guía de Práctica Clínica (GPC) Basada en la evidencia para la promoción del crecimiento, detección temprana y enfoque inicial de alteraciones del crecimiento en niños menores de 10 años. Bogotá: Colciencias, Instituto de Evaluación de Tecnologías en Salud IETS; 2015. Avalaible from: http://gpc.minsalud.gov.co/gpc_sites/Repositorio/Conv_563/GPC_crecimiento/Guia_Completa_C_D.pdf. [cited 2020 Aug 20].

8. Ministerio de Salud y Protección Social. Resolución 2465 de 2016; 2016. Available from: https://www.minsalud.gov.co/Normatividad_Nuevo/Resolucion\%202465\%20de\%202016.pdf. [cited 2020 Feb 1].

9. Hossain M, Choudhury N, Binte KA, Mondal P, Jackson A, Walson J, et al. Evidence-based approaches to childhood stunting in low and middle income countries: a systematic review. Arch Dis Child. 2017; 102(10): 903- 09. http://doi: 10.1136/archdischild-2016-311050.

10. Bamisaye BO, Oladejo T. Association between stunting and obesity among under- five children in urban and rural areas of Oyo State, Nigeria. Malays $\mathrm{J}$ Nutr. 2018; 24(1): 25-4.

11. Farah AM, Nour TY, Endris BS, Gebreyesus SH. Concurrent of stunting and overweight/obesity among children: evidence from Ethiopia. medRxiv. 2020; 127. https://doi.org/10.1101/2020.02.13.20022723.

12. De Onis, Branca F. Childhood stunting: a global perspective. Matern Child Nutr. 2016; 12(1): 12- 6. https://doi.org/10.1111/mcn.12231.

13. Vittora C. Los mil días de oportunidad para intervenciones nutricionales. De la concepción a los dos años de vida. Arch Argent Pediatr. 2012; 110(4) 31117. http://dx.doi.org/10.5546/aap2012.311.

14. Martorell R, Horta BL, Adair LS, Stein AD, Ritcher L, Fall C, et al. Weight gain in the first two years of life is an important predictor of schooling outcomes in pooled analyses from five birth cohorts from low- and middle-income countries. J Nutr. 2010; 140(2): 348-54. https//doi.org/ 3945/jn.109.112300.

15. Quisumbing A, Smith L. Case study \#4-5 of the program: food policy for developing countries: the role of govermentin the global food system; 2007. Available from: https://ecommons.cornell.edu/handle/1813/55670. [cited 2020 Feb 1].

16. World Health Organization. Consejería para la alimentación del lactante y niño; 2009. Available from: https://www.paho.org/hq/dmdocuments/2010/Consejeria\%20para\%20la\%20Alimentacion\%20del\%20Lactante\%20y\%20del\%20nino\%20pequeno_Curso\% [cited 2020 Feb 1].

17. Morrow AL, Guerrero ML, Shults J, Calva J, Lutter C, Bravo J, et al. Efficacy of home-based peer counselling to promote exclusive breastfeeding: a randomised controlled trial. The Lancet. 1999; 353(9160): 1126-31. https://doi.org/ 10.1016/S0140-6736(98)08037-4.

18. Becerra BF, Rocha CL, Fonseca SD, Bermúdez GL. El entorno familiar y social de la madre como factor que promueve o dificulta la lactancia materna. Fac. Med. 2015: 63(2): 217-27. http://dx.doi.org/10.15446/revfacmed.v63n2.44051

19. Lok, KY, Bai, DL, Tarrant, M. Family members infant feeding preferences, maternal breastfeeding exposures and exclusive breastfeeding intentions. Midwifery. 2017; 53: 49-4. https:// doi.org/10.1016/j.midw.2017.07.003.

20. Organización Mundial de la Salud. Lactancia materna exclusiva; 2019. Available from: https://www.who.int/elena/titles/exclusive_breastfeeding/es/. [cited 2020 Feb 1].

21. Instituto Colombiano de Bienestar Familiar. Guías Alimentarias para menores de dos (2) años, mujeres gestantes y madres en periodo de lactancia. Bogotá; 2018. Available from: https://www.icbf.gov.co/sites/default/files/gabasmenor2anos_infografia_2018.pdf. [cited 2020 Feb 1].

22. Haddad L, Alderman H, Appleton S, Song L, Yohannes Y. Reducing child malnutrition: How far does income growthtake us? World Bank Econ Rev. 2003; 17(1): 107-31.

23. Derso T, Tariku A, Biks GA, Wassie MM. Stunting, wasting and associated factors among children aged 6-24 months in Dabat health and demographic surveillance system site: A community based cross-sectional study in Ethiopia. BMC Pediatr. 2017; 17: 96. https://doi.org/ 1186/s12887-017-0848-2.

24. Hong R, Banta JE, Betancourt JA. Relationship between household wealth inequality and chronic childhood under-nutrition in Bangladesh. Int J Equity Health. 2006; 5:15. https://doi.org/ 1186/1475-9276-5-15.

25. Alderman H, Headey DD. How Important is Parental Education for Child Nutrition? World Dev. 2017; 94: 448-64. https://doi.org/10.1016/j.worlddev.2017.02.007.

26. Butta, Z, Das JK, Rizvi A, Gaffey MF, Walker N, Horton S, et al. Evidence-based interventions for improvement of maternal and child nutrition. what can be done and at what cost? Lancet. 382(9890): 452-77. https://doi.org/ 1016/S0140-6736(13)60996-4.

\section{Figures}




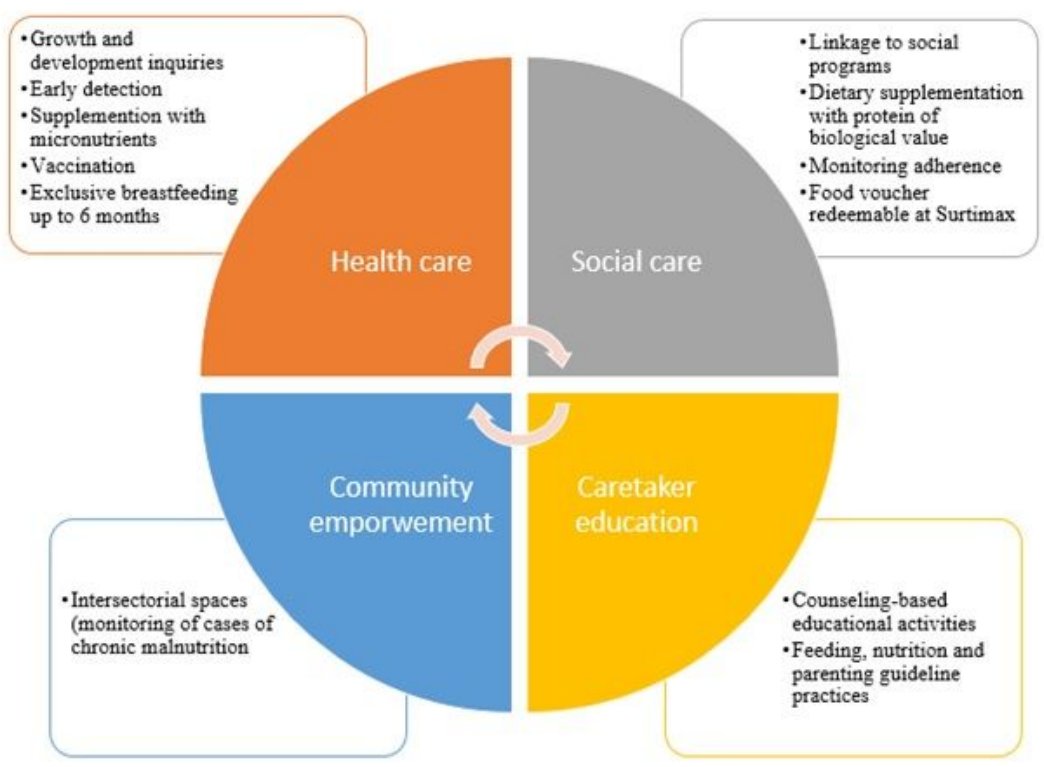

Figure 1

Intervention model applied to the beneficiaries of the study for 10 months

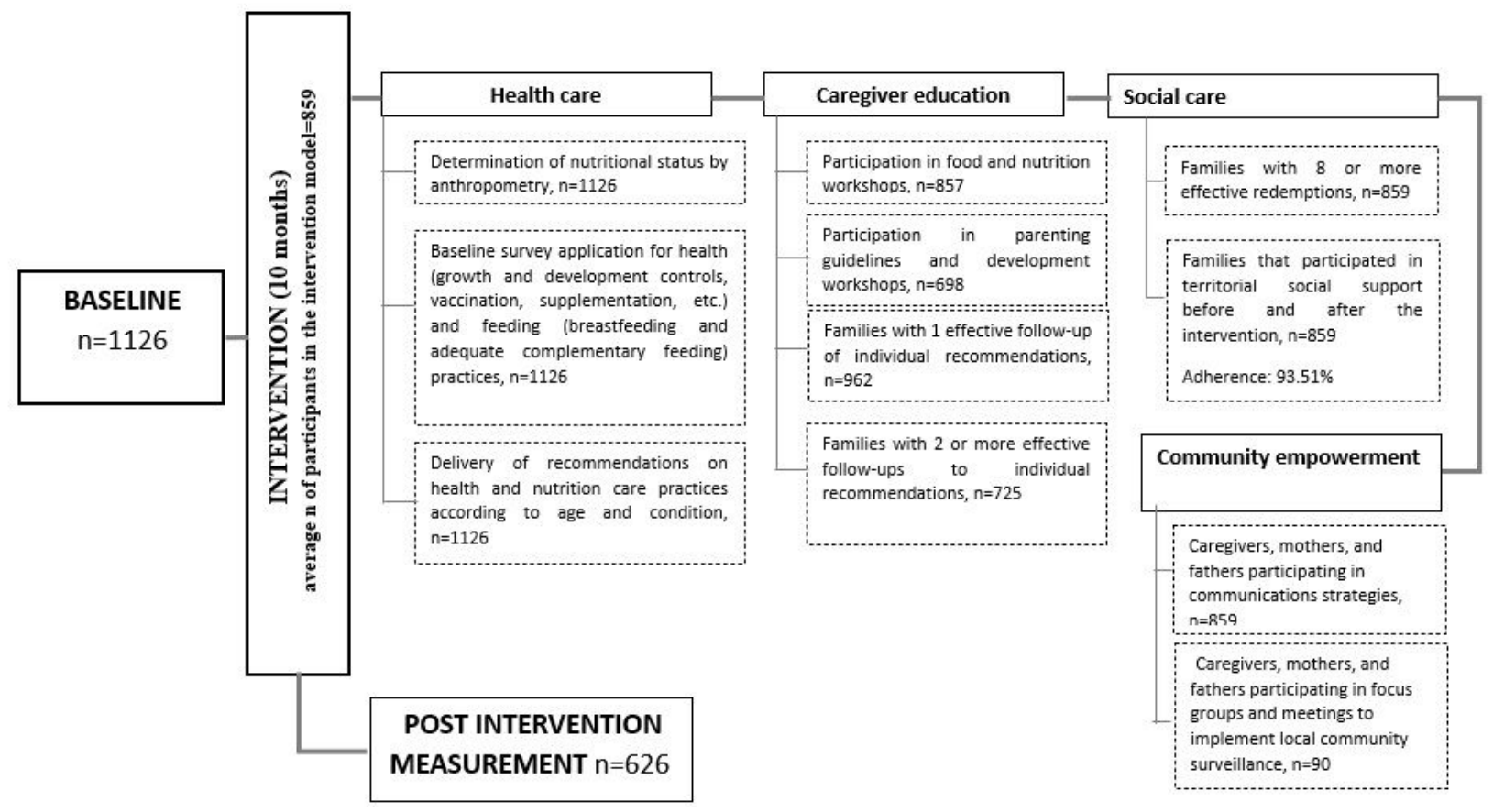

Figure 2

Distribution of study beneficiaries according to participation in the activities defined for the intervention model 


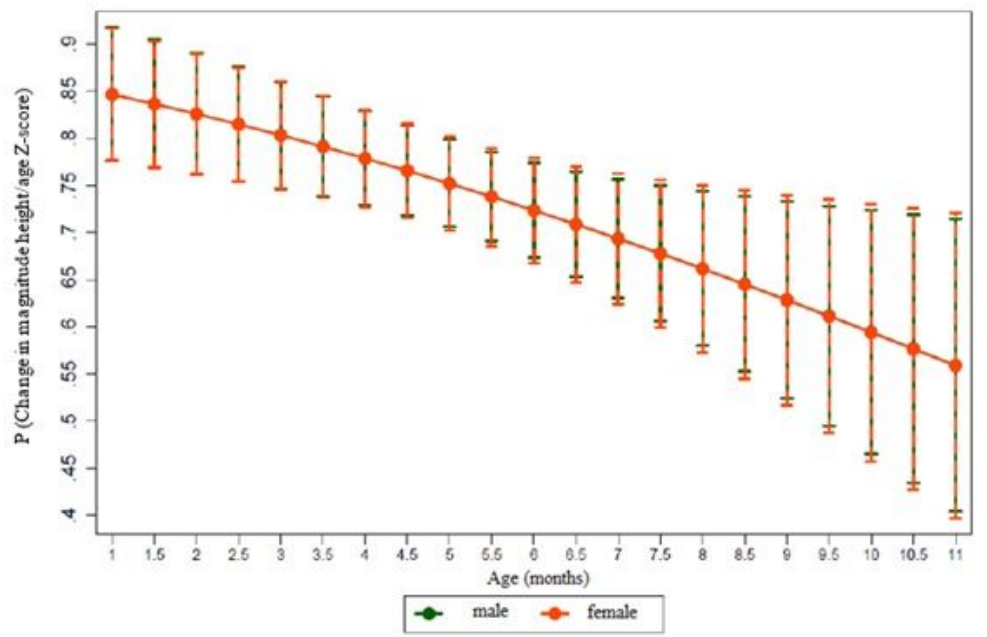

Figure 3

Marginals diagram stratified presenting the probability of approaching or being in the appropriate growth channel

\section{Supplementary Files}

This is a list of supplementary files associated with this preprint. Click to download.

- Additionalfile1.docx

- Additionalfile2.docx

- Additionalfile3.docx

- Additionalfile4.docx 